\title{
水景施設より発生するマイナス FIELD MEASUREMENT OF NEGATIVE イオンの濃度実測 ION CONSENTRATION OF AQUA SCAPE FACILITIES
}

\section{二宮 敦 — $* 1$ 畔柳昭雄 — $* 2$ \\ 渡辺秀俊 - $* 3$ \\ キーワード \\ マイナスイオン，水景施設，平面分布，物理条件}

Keywords :

Negative ion, Aquascape facilities, Distribution of plane, Physical condition

\section{Atsushi NINOMIYA $-* 1$ Hidetoshi WATANABE $-* 3$ \\ Akio KUROYANAGI $-* 2$}

Field measurement of negative ion concentration, temperature, humidity, and relation wind has been done in aquascape facilities in the Funabashi Andersen Park. As a result, shown as follow.

(1) When the negative ion leaves the source, it decreased, but it increased again. (2) There is a negative ion from the fountain within the range of $5 \mathrm{~m}$ distances. (3) The negative ion density indicates a value which there are many things a condition whereby the lee or the humidity are high.

\section{1.はじめに}

空気中には、二種類のイオン（マイナス・プラス）が存在する。 これらイオンは、空気中に存在するマイナスあるいはプラスの電 荷を帯びた原子 (原子群) の総称である。そして、マイナスイオ ンは清浄な空気中に多く存在し、逆にプラスイオンは污染された 空気中に多く存在することが分かっている。また、レナード効果 清1の分裂帯電などにより、マイナスイオンは水辺で多く発生する。 近年、イオンの人体に対する効果が医学分野などで明らかにさ れてきている。それらは、マイナスイオンは人体の副交感神経に 作用し、新陳代謝を良くする、脈拍が落ち着く、最高血圧が静隇 されるなど人体に対し良い効果があり、逆にプラスイオンは交感 神経に作用し、人体には良い効果をもたらさないなどである。ま た、上記のような生理的効果のみならず、マイナスイオンを充満 させた室内において、作業効率が良くなったという作業効率に関 する効果や、人間がリラックスしているときに検出される脳波の 一つである $\alpha$ 波が検出されたなど心理的な効果に関する研究報告 ト〜11'もある。

これらのマイナスイオン関連の研究 1 9の多くは主に屋内で行 われ、マイナスイオン濃度分布把握や長時間の定点測定などが行 われている。一方、屋外での調査·研究は、長時間の定点測定を除 けばほとんど行われておらず、マイナスイオン濃度分布の把握や 諸物理量との関係性の把握などの調査·研究は緒についたばかり と言える。また、水辺でのマイナスイオンの効果を対象に行った 研究 8.9' は極めて少ない。

そのような中、筆者らは今後の水景施設整備において、水景施

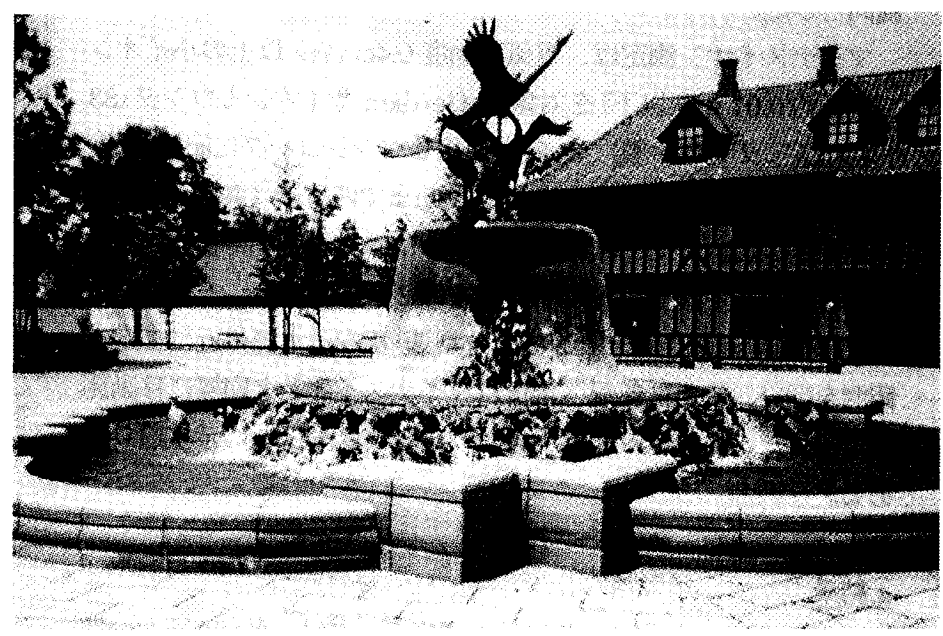

図-1 対象噴水図面及び写真

表-1 対象地及び測定期間

\begin{tabular}{|c|c|}
\hline 測定場所 & 千葉県船橋市 アンデルセン公園内噴水 \\
\hline 噴水の特徵 & $\begin{array}{c}\text { 高さ } 245 \mathrm{~cm} \text { (出水時 } 300 \mathrm{~cm} \text { ）、面積 } 53 \mathrm{~m}^{2} 、 \\
\text { 水量 } 8.3 \mathrm{t} / \mathrm{min} \text { 、使用ポンプ } 29.55 \mathrm{kw}\end{array}$ \\
\hline 測定期間 & 1998 年 8 月 4 日〜25日期間中の晴れた日 \\
\hline
\end{tabular}
設に期待される心地よさや清涼感など視覚的効果以外に、マイナ スイオンが人体へもたらす効果に注目することで、水景施設の新 しい在り方を検討しようと研究を行ってきた。そのため、前報で は水景施設（特に水の動きの激しい噴水や壁泉、滝など）におけ るマイナスイオンと人間の心理との関係を把握してきた。か 今後、水景施設のもたらす水辺におけるマイナスイオンの効果

*1 Graduate School, Nihon Univ

日本大学大学院理工学研究科海洋建築工学専攻

(干274-8503 船橋市習志野台7-24-1 241A)

*2 日本大学理工学部海洋建築工学科 助教授・工博

*3 三洋テクノマリン 上博
*2 Assoc. Prof., Dept. of Oceanic Architecture and Engineering College of Science \& Technology, Nihon Univ., Dr. Eng.

*3 Sanyo Techno Marine Inc., Dr. Eng. 
を明らかにすることは重要と思われる。

\section{2. 研究目的}

筆者らはこれまで、親水公園内の水景施設付近でのマイナスイ オン濃度と人間の心理との関係性を明らかにしてきた ${ }^{8}$ 。しかし ながら、既報の調查では施設付近のマイナスイオン濃度分布等は 考慮に入っておらず、このことが反省点として挙げられる。

そこで、本研究は水景施設付近におけるマイナスイオン発生量 及び分布傾向を把握することを目的とし、噴水付近でのマイナス イオン発生濃度、噴水付近でのマイナスイオンの存在範囲、そし て、マイナスイオン濃度に影響を持つ物理的要因の調査を行うこ ととした。

\section{3. 研究方法}

本研究の対象地は、既往研究棌により明らかになったマイナス イオンの多く発生している水景施設形態、施設の周囲に広い空地 があること、水量などの条件に基づき選定し、千葉県船橋市アン デルセン公園内の噴水とした（図一 1 参照）。

調査項目は、今後人間の心理との関連を把握することを考慮し、 人間の心理に関係している様々な環境の内、熱環境を中心に項目 を選定し、噴水付近のマイナスイオン濃度、気温、湿度、風速、

風向とした。

マイナスイオン測定は、電気移動度 $0.4 \mathrm{~cm}^{2} / \mathrm{vs}$ 以上の小イオン (粒径約 $0.01 \mu \mathrm{m}$ 以下) を対象に、Gerdien 型イオンカウンタ (83 - 1001A、ダン科学製) を 2 台使用しペンレコーダに記録した。

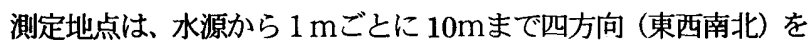
移動測定した。また、測定スケジュールは、測定時間 5 分間、機 器の移動と測定機器が安定するまでの 2 分間を取り、一測定 7 分 間で 15 日間計測を行った。また、風速·風向は水源付近にて定点 観測を行い、また、気温・湿度はマイナスイオンと同様に移動測 定で行った。噴水の特徴及び測定の詳細は表-1、2 に示す通りで ある。

\section{4.結果}

今回、測定したマイナスイオン濃度デー夕は、測定時間 5 分間 の最大值、平均值、最小值の三つの形式で処理した。また、マイ ナスイオンは天候の悪化に伴い存在量が多くなる特徵がある。本 稿では水景施設から発生するマイナスイオンの特徴を捉えること が目的であるので、天候が良好であった日の值を使用している。

水辺のマイナスイオン濃度と比較するために測定した芝生上 の濃度の平均值は $0.3 \times 10^{3}$ 個/ $\mathrm{cc}$ であった。既往研究 1,2,3 と、通常の大気中には約 $0.1 \sim 0.2 \times 10^{3}$ 個/ $/ \mathrm{cc}$ の濃度があると報告 されており、通常の值より若干高い濃度となっている。

\section{1.風上、風下におけるイオン湦度実測}

図-2 は風上及び風下別にイオン濃度の平均值分布を示した図

である。測定中の風速は $1.4 \sim 3.0 \mathrm{~m} / \mathrm{sec}$ の南風であった。

まず風下の北側では、0m付近において測定中の最高濃度を示 し、6.3×103個/cc であった。また、水源から距離を置くに従い濃 度は明確な减少傾向を示すが、 $6 \mathrm{~m}$ 付近で再增加し $0.8 \times 10^{3}$ 個 $/ \mathrm{cc}$ を示した。次に、風上の南側では、 $0 \mathrm{~m}$ 付近で $0.4 \times 10^{3}$ 個/ $\mathrm{cc}$ と
表-2 測定使用機器及び方法

\begin{tabular}{|c|c|c|}
\hline \multicolumn{3}{|c|}{ 測定使用機器・方法 } \\
\hline \multirow{4}{*}{$\begin{array}{l}\text { イオン } \\
\text { 濃度 }\end{array}$} & 使用機器 & イオンカウンタ 83-1001A （ダン科学製） \\
\hline & \multirow{2}{*}{ 測定地点 } & 噴水付近を $10 \mathrm{~m}$ まで $1 \mathrm{~m}$ ごとに測定 \\
\hline & & 地上より約 $1 \mathrm{~m}$ 地点 \\
\hline & スケジュール & 計測 5 分移動 2 分、移動測定 7 分 \\
\hline \multirow{3}{*}{$\begin{array}{l}\text { 気温 } \\
\text { 湿度 }\end{array}$} & 使用機器 & 乾湿球温湿度計 \\
\hline & 測定地点 & 噴水付近を $10 \mathrm{~m}$ まで $1 \mathrm{~m}$ ごとに測定 \\
\hline & スケジュール & 計測 5 分移動 2 分、移動測定 7 分 \\
\hline \multirow{3}{*}{$\begin{array}{l}\text { 風速 } \\
\text { 風向 }\end{array}$} & 使用機器 & ウェザ - リンクIII、ウェザ PC \\
\hline & 測定地点 & 水源付近で定点測定 \\
\hline & スケジュール & イオン測定中、1 分ごとに測定 \\
\hline
\end{tabular}

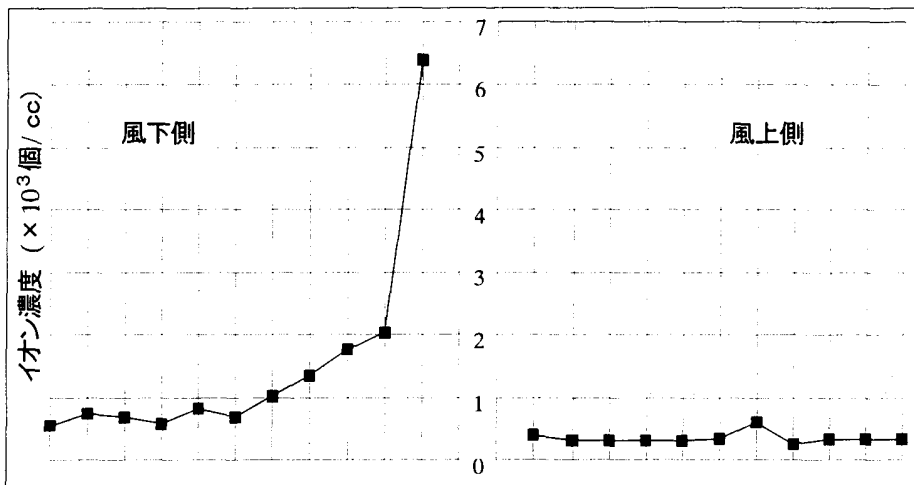

$\begin{array}{lllllllllll}10 & 9 & 8 & 7 & 6 & 5 & 4 & 3 & 2 & 1 & 0\end{array}$

$\begin{array}{lllllllllll}0 & 1 & 2 & 3 & 4 & 5 & 6 & 7 & 8 & 9 & 10\end{array}$

図-2 風上·風下別のマイナスイオン濃度分布 噴水からの距離 $(\mathrm{m})$

16

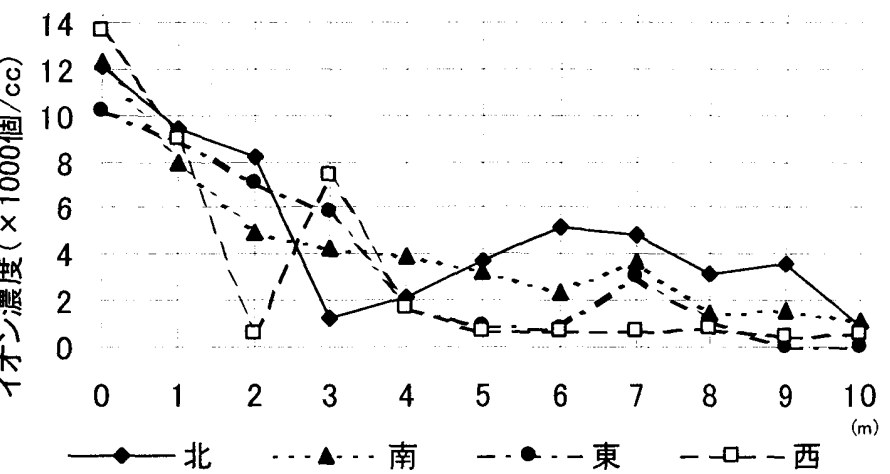

図-3 四方向のマイナスイオン濃度（最大値）

濃度は風下に比べて低い。また、僅かではあるが風下と同様に距 離を置くに従い減少し、 $6 \mathrm{~m}$ 付近で再增加し、最高值は $0.6 \times 10^{3}$ 個/ccを示した。

全体的に風下では水源から急激な減少傾向が見られるが、風上 では水源から距離をおいても僅かな減少傾向であった。また、風 下はマイナスイオン濃度が高く、風上と比べて最も濃度差の少な い $6 \mathrm{~m}$ 地点でも約 1.3 倍大きい濃度を示した。再増加する特徴は、 レナード効果によるものと考えられる。

\section{2.四方向のイオン浱度実測}

図一 3 は噴水を中心に四方向（東西南北）測定した最大值、図 -4 は平均值の結果を示したものである。測定中の風速は $1 \mathrm{~m} / \mathrm{sec}$ 以下の南風であった。これらの図を見ると、北、南、東側の各方 向のイオン濃度は、最大值では噴水から 0mの地点で、また、平 均值では $1 \mathrm{~m}$ 地点で最高值を示し、最大值 $10 \sim 14 \times 10^{3}$ 個/ $\mathrm{cc}$ 、平 
均值 $2 \sim 7 \times 10^{3}$ 個/cc であることが分かる。そして、噴水から距離 を置くに従い濃度は減少していくが、7m付近で各方向の濃度は 再び増加し、最大值 $3 \sim 6 \times 10^{3}$ 個/cc、平均值 $0.5 \sim 1.5 \times 10^{3}$ 個/ $\mathrm{cc}$ となった。また、西側の測定では $0 \mathrm{~m}$ 地点で最高值を示し、それ から距離を置くに従い減少していくが、3m 地点で再増加する傾 向が見られた。

噴水からの距離が離れるに従って濃度が減少すること、そして 再増加することは全方向において共通に見られた特徴である。

図一5 は図-4のデータを使用し、噴水付近のマイナスイオン 濃度分布を平面的に示した図である。

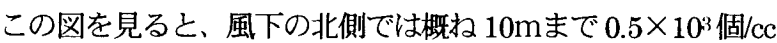
程度濃度があるのに対し、風上の南側では $5 \mathrm{~m}$ 以遠ではほとんど マイナスイオンは存在していないことが分かる。また、東、西側 では概ね $7 \mathrm{~m}$ 付近で $0.5 \times 10^{3}$ 個/ $/ \mathrm{cc}$ となっていることが分かる。

前出の芝生上のマイナスイオン濃度 $\left(0.3 \times 10^{3}\right.$ 個 $\left./ \mathrm{cc}\right)$ を考慮に 入れると、この噴水では南側約 $5 \mathrm{~m}$ 、南以外の方角では約 $10 \mathrm{~m}$ で 芝生上のマイナスイオン濃度と同程度の值となることが分かる。

\section{3 風速の違いによるマイナスイオン湌度}

図-6 は風速とマイナスイオン濃度の関係を、水源からの距離 別に示した図である。なお、この図では風速をビューフォート風 力階級表 $12.13^{\prime}$ に基づき〜 $0.3 \mathrm{~m} / \mathrm{sec}$ を階級 $0 、 0.4 \sim 1.5 \mathrm{~m} / \mathrm{sec}$ を階 級 1、1.6 3.3m/sec を階級 2 の三段階に分類し、更にそれらを 風上又は風下に分類し表記している。この図を見ると、風下の場 合に概ねマイナスイオン濃度が大きくなる傾向にあることが分か る。そして風の強弱では、弱風の方がマイナスイオン濃度は大き な值を示していることが分かる。

また、水源からの距離別に見ると、水源からの距離 0 ～4m地点 までは風下又は風が弱い条件の時、マイナスイオン濃度が大きく なる傾向にある。次に、約 $5 \mathrm{~m}$ 地点で各条件に関係なく濃度が小 さくなり、6〜8m地点で再増加するがこれらの地点では、風上又 は風下の明確な差は見られなかった。

\section{4 湿度とマイナスイオン濃度比較}

表 -3 は、噴水から $2 \mathrm{~m}$ の地点で測定したマイナスイオン濃度 （平均值を使用）等の測定結果を測定した時間帯により分類し表 示したものである。

測定項目の平均值を見ると、マイナスイオン濃度と湿度は午後 の時間帯で若干高い値を示していることが分かる。また、気温で は時間帯による明確な差異は見られないことが分かる。

図-7 は表一2の值を用い、マイナスイオン濃度（平均值）と 湿度、風の強弱、風向の関係を示した図である。なお、マイナス イオンの值は湿度の降順に並べ替え、図中に湿度とマイナスイオ ン濃度の平均值を加えて表示してある。

この図を見ると、マイナスイオン濃度にばらつきがあることが 分かる。また、マイナスイオン濃度は湿度が高くなるほど大きな 値を示す傾向にあることが分かる。

次に、マイナスイオン濃度が平均值を超える場合を見てみると、 $0.3 \mathrm{~m} / \mathrm{sec}$ 以下の弱風であること、風下であること、湿度が平均值 より大きな值を示すこと、のいずれかの条件を満たしていること が分かる。逆に風上や $1.6 \mathrm{~m} / \mathrm{sec}$ を越える風力の場合、マイナス

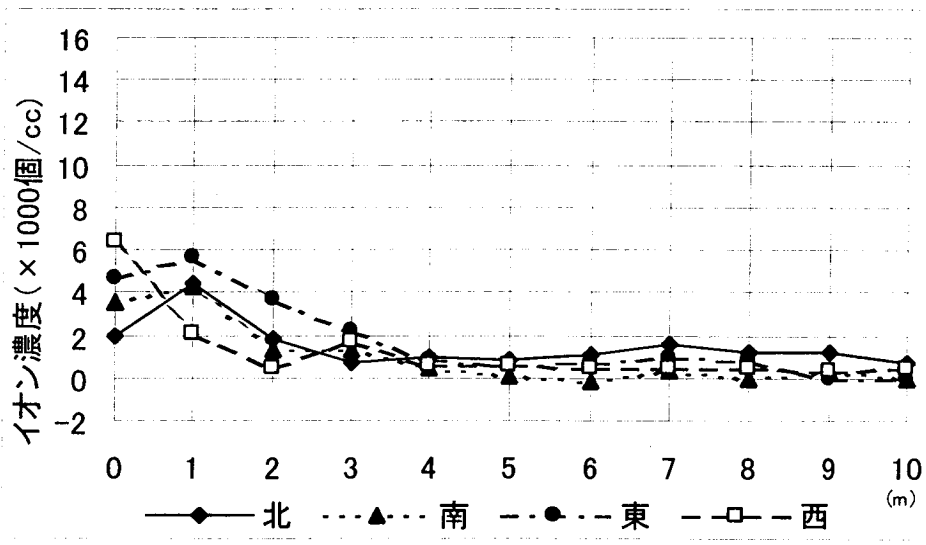

図-4 四方向のマイナスイオン濃度（平均值）

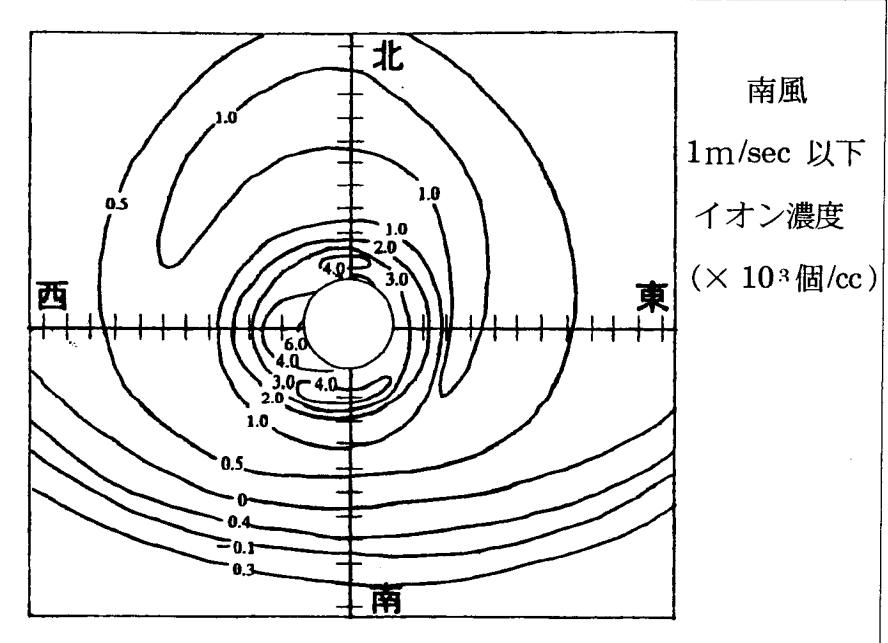

図－5＼cjkstart四方向のマイナスイオン濃度濃度分布（平均值）

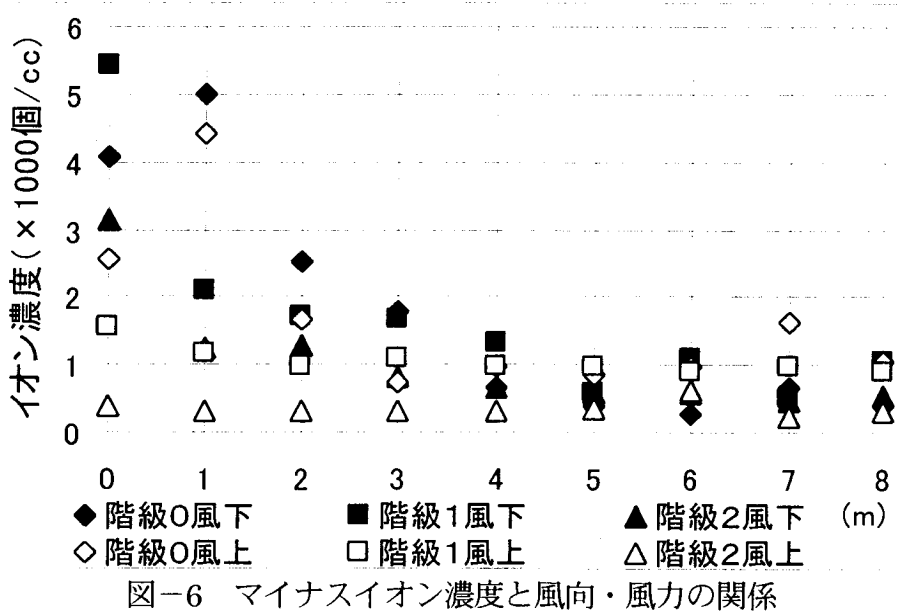

イオン濃度は平均值を超えているものは少ないことが分かる。

\section{5.おわりに}

今回の調査で得られた結果を以下に示す。

(1)マイナスイオン動向の特徴として、濃度は水源から離れるに従 って減少していく。そして、風下側で $5 \sim 7 \mathrm{~m}$ 、風上側で $3 \sim 6 \mathrm{~m}$ 付近で再增加することを把握した。

(2)今回の対象噴水でのマイナスイオン存在範囲は、水源から概小 $5 \mathrm{~m}$ までであることを把握した。

(3)マイナスイオンは風の影響を受けやすく、マイナスイオン濃度 
は弱風または風下の場合に大きくなる傾向にあることを把握 した。

(4)湿度が高い程マイナスイオン濃度は大きくなる傾向のあるこ とを把握した。

本研究の結果、マイナスイオンと水源からの距離との関係、マ イナスイオンの存在範井、マイナスイオン濃度に関係する諸物理 環境等を把握することができた。

一方、マイナスイオンの人体に与える効果として、疾患の予防 及び衛生に対しては、103個/cc 程度の濃度で良好な影響を与える とする報告らがある。こうしたことを踏まえると、今後の水景施 設の新しいあり方の一つとしては、従来までの視覚的な効果だけ ではなく、人間の精神面・心理面に㗢きかけることによってヒーリ ング効果やリラクゼーション効果を与えるような施設としての可 能性があると思われる。

本調査は夏季のみの調査であり、水景施設付近でのマイナスイ オンの特徵を全て網羅しているとは言い難く、四季を通じた調査 や今回見られたマイナスイオンの特徴の詳細な調査や、今回の研 究では触れなかったが近年問題となっている、水景施設での水質 との関係など追究する余地はあると考える。

\section{䝰辞}

本研究は親水工学研究室卒研生石坂仁君の卒業研究を基に作成したもの であり、本調査を行うに当って、千葉県船橋市アンデルセン公園職員の方々、 (株)フジタの佐藤降満様、島田洋様、本研究室ゼミ生小林誠君には多大なご 協力を受けました。ここに記して感謝の意を表します。

注1）レナード効果：1890 位、Elster, Geitcrが,オーストリア・アルプスの|は

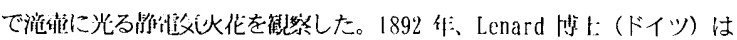

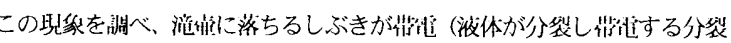

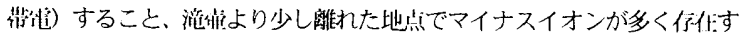

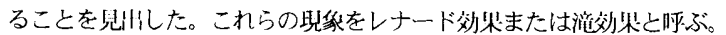

Kruger:A.P\&Reed.E.J : Biological impact of small air ions : Science vol193.p1209.1976

2) Hawkins.H.H\&Baker : Air ions and human performance : Ergonomics voll.p273.1978

3) C.ALaws : Air ions in the working enoviorment : The heating and Ventialating Engineer: 1982.5

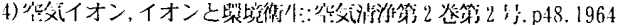

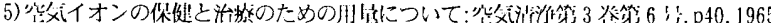

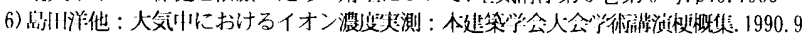

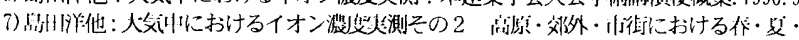

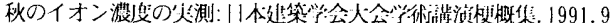

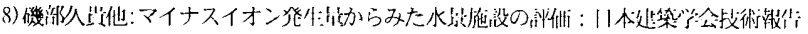
倬. 6 第 $6 \%$. p131.1998.10

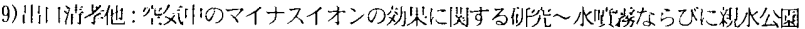

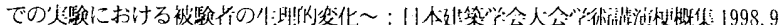
10)仪健次：体に主く效くマイナスイオン: $\mathrm{KK}$ ペストセラーズ.1996.12

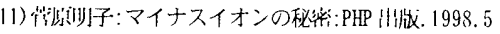

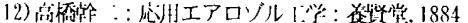

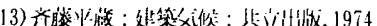

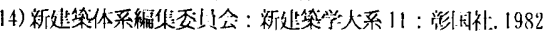

15)イオンクラスタエアー:vol.3..102.1996

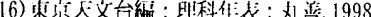

17) A.D.Penwarden : Acceptable Wind Speeds in Towns:Building :Science.Vol8 p259

18) Biological Impact of Small Air Ions:Science, Vol. 1.p193.1976.9

19) Air ions and Hnman Perfomance:ERGONOMICS vol21 no4.p273.1978
表 -3 测定結果

\begin{tabular}{|c|c|c|c|c|c|c|}
\hline $\begin{array}{c}\text { 測定時 } \\
\text { 間帯 }\end{array}$ & 測定地点 & $\begin{array}{c}\text { マイナスイオン濃度 } \\
\left(\times 10^{3} \text { 個/cc }\right)\end{array}$ & $\begin{array}{c}\text { 湿度 } \\
(\%)\end{array}$ & $\begin{array}{l}\text { 気温 } \\
\left({ }^{\circ} \mathrm{C}\right)\end{array}$ & $\begin{array}{c}\text { 風速 } \\
(\mathrm{m} / \mathrm{sec})\end{array}$ & $\begin{array}{l}\text { 風向 } \\
\text { 風速 }\end{array}$ \\
\hline \multirow{10}{*}{$\begin{array}{l}\text { 午 } \\
\text { 前 } \\
\text { 中 } \\
\text { 方 } \\
\frac{\vec{N}}{\mathrm{O}} \\
\vdots\end{array}$} & 北 & 0.47 & 68.10 & 37.50 & 0.16 & $\nabla$ \\
\hline & 西 & 0.50 & 71.90 & 34.00 & 0.24 & $\nabla$ \\
\hline & 北 & 0.56 & 79.70 & 31.00 & 0.52 & - \\
\hline & 北 & 0.94 & 83.20 & 32.50 & 0.84 & 0 \\
\hline & 東 & 1.21 & 60.80 & 38.00 & 0.70 & - \\
\hline & 東 & 1.48 & 61.40 & 39.00 & 0.98 & - \\
\hline & 東 & 1.67 & 86.20 & 31.00 & 1.51 & $\Delta$ \\
\hline & 西 & 1.70 & 64.70 & 36.00 & 1.40 & $\Delta$ \\
\hline & 西 & 3.40 & 75.20 & 35.00 & 0.00 & $\nabla$ \\
\hline & 平均値 & 1.33 & 72.36 & 34.89 & 0.71 & 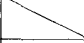 \\
\hline \multirow{10}{*}{ 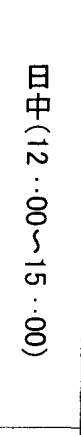 } & 東 & 0.33 & 64.70 & 36.00 & 2.12 & - \\
\hline & 東 & 0.78 & 52.80 & 40.00 & 0.34 & - \\
\hline & 東 & 1.26 & 58.70 & 38.50 & 0.42 & - \\
\hline & 南 & 1.38 & 83.10 & 31.50 & 0.08 & $\nabla$ \\
\hline & 東 & 1.67 & 89.50 & 30.50 & 1.14 & - \\
\hline & 北 & 1.75 & 66.80 & 35.00 & 2.40 & OA \\
\hline & 北 & 1.84 & 67.80 & 37.00 & 0.00 & $\nabla$ \\
\hline & 南 & 2.18 & 89.50 & 30.50 & 0.74 & 0 \\
\hline & 南 & 2.62 & 73.90 & 32.00 & 0.50 & - \\
\hline & 平均値 & 1.53 & 71.87 & 34.56 & 0.86 & 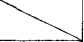 \\
\hline \multirow{9}{*}{ 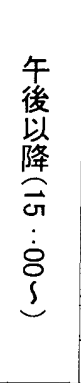 } & 南 & 0.30 & 68.50 & 33.00 & 2.68 & OA \\
\hline & 東 & 0.73 & 71.30 & 39.00 & 0.08 & $\nabla$ \\
\hline & 東 & 1.43 & 58.70 & 38.50 & 0.60 & - \\
\hline & 西 & 1.50 & 86.10 & 30.50 & 0.00 & $\nabla$ \\
\hline & 西 & 1.55 & 86.20 & 31.00 & 0.04 & $0 \nabla$ \\
\hline & 南 & 2.90 & 86.20 & 31.00 & 0.75 & $\mathrm{O}$ \\
\hline & 東 & 3.06 & 84.60 & 32.00 & 0.18 & $\nabla$ \\
\hline & 東 & 3.62 & 83.20 & 32.00 & 0.00 & $\nabla$ \\
\hline & 平均値 & 1.89 & 78.10 & 33.38 & 0.54 & 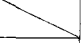 \\
\hline
\end{tabular}

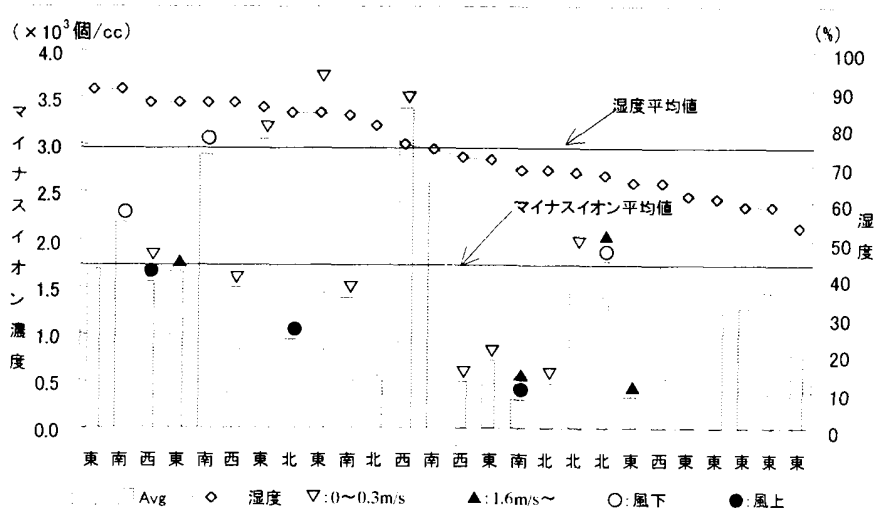

図-7 マイナスイオンと湿度・風向・風力の関係 [1999年 3 月 16 日原稿受理 1999 年 7 月 27 日採用決定］ 